\title{
Development of Poly Herbal Granules and its Anti-Fatigue Efficacy in Swiss Mice
}

\author{
Luna Dutta Baruah ${ }^{1}$, Rohini Devi ${ }^{3}$, Dhruba Jyoti Nath², \\ Vijaya Nalwade ${ }^{3}$, Asha Arya ${ }^{3}$ and Sudhir Rajurkar ${ }^{4}$
}

\author{
${ }^{1}$ Department of Food Science and Nutrition, Assam Agricultural University, \\ Jorhat-785013, Assam, India
}

${ }^{2}$ Department of Soil Science, Assam Agricultural University, Jorhat-785013, Assam, India

${ }^{3}$ Department of Food and Nutrition, Vasantrao Naik Marathwada Agricultural University, Parbhani-431402, Maharashtra, India

${ }^{4}$ Department of Pharmacology and Toxicology, College of Veterinary and Animal Sciences, Vasantrao Naik Marathwada Agricultural University, Parbhani-431402, Maharashtra, India

*Corresponding author

\section{A B S T R A C T}

\section{Keywords}

Polyherbal granules, Haemoglobin, Forced swimming tests, Blood glucose.

Article Info

Accepted:

20 March 2017

Available Online:

10 April 2017
The current study sought to investigate the anti-fatigue efficacy of poly herbal granule (PHG) formulations of the extracts of Asparagus racemosus, Chlorophytum borivilianum, Tinospora cordifolia, Tribulus terrestris and Withania somnifera enriched with general tonic and health promoting properties based on Aloe vera gel and soyabean whey in Swiss mice. The nutrient compositions of the selected PHG exhibited that the carbohydrates were the major constituents in both AVII and SBWII, followed by protein and total ash. Fat

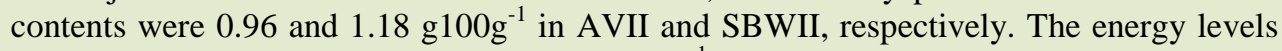

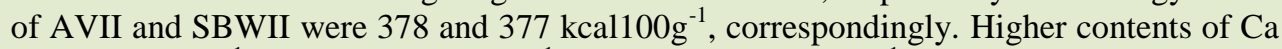

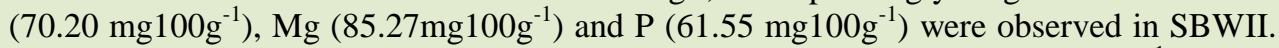
The trace elements revealed that, $\mathrm{Zn}$ and Fe content were 1.84 and $8.63 \mathrm{mg} 100 \mathrm{~g}^{-1}$ in AVII and 1.85 and $7.85 \mathrm{mg} 100 \mathrm{~g}^{-1}$ in SBWII, respectively. The retention and stability of Vitamin $\mathrm{C}$, total sugar, reducing sugar and non-reducing sugar for 270 days illustrated the storage life of the product in ambient condition. The body weight of mice, swimming time and corresponding biochemical parameters including haemoglobin, serum protein and blood glucose level were measured by standard method. The oral administration with PHG supplement for 30 days markedly increased the body weight (11.40-11.80\%), haemoglobin (11.82-12.46\%), serum protein (3.77-6.02\%) of the mice. Following forced swimming test (FST), prolonged exhaustive exercise time of 231.02 (AVII), 237.50 (SBWII) minutes were recorded for PHG supplemented groups which were 36.23 (AVII) and 37.97 (SBWII) per cent longer than that of the control group. The minute increase of blood glucose levels (4.51-4.37\%) in PHG supplemented Swiss mice after FST as compared to tremendous increase in blood glucose level $(40.07 \%)$ in the control group illustrated the anti-fatigue activity of PHG.

\section{Introduction}

Fatigue is the consequence of exertion beyond one's normal ability which is defined as an exercise induced inability to perform the expected or desired work output (Ament and 
Verkerke, 2009; Mehta and Agnew, 2012). Physiological, psychological and disease theories are the three major aspects of fatigue (Ament and Verkerke, 2009) which leads to depletion of energy source and accumulation of excess metabolites (Coombes et al., 2002) including reactive free radicals resulting to tissue damage (Nybo, 2003; You and Zhao, 2011). Energetic deficiency both during dynamic and static exercise plays a major role in the aetiology of muscle fatigue. The available therapies or pharmacological drugs for the treatment of fatigue are very limited (Uthayathas et al., 2007), which necessitate potential alternatives from the extracts of traditional herbs and their respective performance of action are worth investigating (Tharakan et al., 2005). Herbs or other botanicals and their extracts or concentrates mentioned in literature as dietary supplements (Sen and Chakraborty, 2016) have the potential to mitigate fatigue, accelerate the elimination of fatigue-related metabolites and improve exercise performance (Tharakan et al., 2005, Lee et al., 2012 and Zink 2016). The herbal plants viz., Aloe vera (Aloe barbadensis Miller), Aspargus racemosus, Chlorophytum borivilianum, Tinospora cordifolia, Tribullus terrestris and Withania somnifera have been found to exhibit therapeutic properties like adaptogenic, immunostimulant, tonic as well as to promote general health (Radha and Laxmipriya, 2015; Bopana and Saxena, 2007; Kenjale et al., 2007; Shirolkar et al., 2013; Lamba et al., 2011; Mukhopadhya et al., 2001). In this context, the diversity of nutritional constituents from these herbs could be investigated for their possible role in alleviating fatigue generated during exercise performance. However, there is a need to approach scientific proof and clinical validation of herbal extracts with chemical standardization (Niranjan and Kanaki, 2008), biological assays, animal models and clinical trials for development of commercially viable poly herbal formulation (Heng et al., 2013 and WHO, 2013). The safety and efficacy of herbal products have been ascertained from the history of clinical application (Bae et al., 2015) as well as pharmacological studies based on animal model and its clinical evaluation (Afolabi et al., 2012). Forced swimming test (FST) in mice is a reliable model (Holmes, 2003) which can be employed to depict the use of the poly herbal extracts for achieving meaningful outcomes similar to the effectiveness desired in humans (Borsini and Meli, 1988). Considering the available history for the individual plants of safe use over the period having the therapeutic values such as adaptogenic, immunostimulant, general tonic and health promoting property the present study reports the preparation of poly herbal formulation, its nutritional characteristics and to evaluate in vivo efficacy in alleviating fatigue in Swiss mice

\section{Materials and Methods}

\section{Extraction and preparation of poly herbal mixture}

The botanical raw material consisting of five medicinal plants $W$. somnifera L. Dunal (roots), T. terrestris Linn. (dried spiny fruit), T. cordifolia (T.) Miers (stem), $C$. borivilianum (tuberous roots) and $A$. racemosus Wild. (roots), were procured from the authenticated local market of Parbhani, Maharashtra, India. Each raw material was washed separately, dried, powdered $(75 \mu \mathrm{m}$ sieve) and was packed in airtight container for further analysis.

The individual plant extracts were taken in equal parts $(w / w)$, mixed together and passed through $75 \mu \mathrm{m}$ sieve to obtain a homogenized poly herbal mixture (PHM). The base material for development of poly herbal supplement was done using $A$. veragel and soybean whey. 


\section{Preparation of base materials}

The leaves were collected, washed and the latex was drain out to obtain the aloe fillet and kept in the freezer $\left(4^{0} \mathrm{C}\right)$. The freezed aloe fillets were crushed in a grinder and filtered to obtain the $A$. vera gel extract.

Fresh soybean seeds were cleaned, washed and soaked in water (3:1 ratio) for 6 hours. The soaked beans were dehulled and ground with hot water (1:8 ratio) in a grinder to obtain the milky pulp. The pulp was boiled for 20 minutes and strained through sterilized muslin cloth to extract the soymilk which was curdled by addition of citric acid $(0.2 \%)$. The whey water was collected by straining the curdled soymilk. The $A$. veragel and soyabean bean whey were used for formulation of supplement and its nutritional analysis.

\section{Formulation of poly herbal granules}

Six different variants with three replications of granules were prepared by dissolving water $(20 \mathrm{~mL})$, base materials $(20 \mathrm{~mL} ; A$. veragel/soya whey), citric acid $(3.0 \%)$ and sugar at different concentration and heated to obtain a syrup (two thread consistency) to which PHM was added and stirred continuously for 3-5 minutes over low flame. Further, the granular mixture was dried at $45^{\circ} \mathrm{C}$ for 1 hour and passed through $500 \mu \mathrm{m}$ sieve to obtain uniform sized granules and stored in air-tight labeled containers. The granules were dissolved in water at $7.1 \%$ for organoleptic evaluation (Table 1).

\section{Organoleptic evaluation}

A Five-Point Hedonic Rating Scale (Amerine et al., 1965) was used for rating the attributes, viz., colour, taste, flavour and overall acceptability and the evaluation was carried out by 10 semi trained panelists based on their sensitivity to different tastes.

\section{Chemical properties}

The individual plant extracts and the formulated poly herbal granules (PHG) were analyzed in triplicates for moisture, protein, fat, total mineral, iron $(\mathrm{Fe})$, copper $(\mathrm{Cu})$, zinc $(\mathrm{Zn})$, calcium $(\mathrm{Ca})$, magnesium $(\mathrm{Mg})$ and phosphorus (P) content. Moisture, protein and fat were estimated by AOAC (1996) method while the total carbohydrates content was found out by difference method [100 (proteins + fats + moisture + ash in percentage)] (NIN, 1983) and vitamin C by titration method (AOAC, 1996). Energy value was computed indirectly using energy value for total carbohydrate, protein and fat. The content of $\mathrm{Fe}, \mathrm{Cu}$, and $\mathrm{Zn}$ were analyzed by atomic absorption spectrophotometer (Perkin R Elner Model 3110). Further, analysis of Ca, $\mathrm{Mg}$ and $\mathrm{P}$ was carried out by procedure given by Gupta (2000).

\section{Assessment of shelf life of granules}

The shelf life of the developed granules on storage was studied at $0,30,60,90,180$ and 270daysfollowing organoleptic as well as analytical evaluation. Under analytical evaluation the products were analyzed for total sugar, reducing sugar, non- reducing sugar and vitamin $\mathrm{C}$. The total sugars were determined following the method of Dubois $e t$ al., (1956). Reducing sugars and nonreducing sugars were determined by NelsonSomogyi method (Somogyi 1952), whereas vitamin $\mathrm{C}$ was determined by AOAC method (AOAC, 1996).

\section{In vivo evaluation in Swiss mice}

Twenty six male Swiss mice weighing $25+5 \mathrm{~g}$ with specific pathogen-free conditions were purchased from M/S. Shree Farms, Tirpude Bhawan, Z.P. Square, NH-6, Bhandara (M.S.) and maintained in the Department of Veterinary Pharmacology and Toxicology, 
College of Veterinary and Animal Sciences, M.A.F.S.U., Parbhani (M.S.). The Swiss mice were given one week to acclimatize to the environment and were maintained on ad libitum with free access to clean fresh drinking water and housed at 12-h light/dark cycle at room temperature $\left(23 \pm 2{ }^{\circ} \mathrm{C}\right)$. Dried clean husk was used as bedding material which was changed on alternate days. The due approval was obtained for the planned protocol from the Institutional Animal Ethical Committee (IAEC) which conformed to the recommended guidelines of the Committee for the Purpose of Control and Supervision of Experiment on Animal (CPCSEA), Ministry of Social Justice and Empowerment, Government of India. In the experiment, the animals were drawn at random into three groups as treatment (Group I, Group II and Group III) in which group I consisted of6 mice and group II and group III consisted with 10 mice each as replication, respectively. The treatment was administered through oral gavage for Group II and Group III with developed PHG viz., AVII and SBWII respectively while Group I received distilled water@ $0500 \mathrm{mgkg}^{-1}$ body weight per day in volumes of $0.15 \mathrm{~mL}$ per mouse in addition to their normal feeding once a day for 30 consecutive days.

\section{Assessment of anti-fatigue activity}

The mice were habitated to laboratory housing for 1 week prior to the start of the experiment. The mice were forced to perform swimming exercise in water tank $(25 \mathrm{~cm} \mathrm{x}$ $35 \mathrm{~cm} \times 30 \mathrm{~cm}$ ) containing fresh water up to a depth of $25 \mathrm{~cm}$ at a temperature of $30^{\circ} \mathrm{C}+$ $1^{0} \mathrm{C}$. The animal were considered fatigued when they were unable to rise to the surface for 5 seconds (Ikeuchi et al., 2006) and were unable to sustain themselves, so rescued at that stage. Actual time of swimming of individual animals was recorded. The swimming exercise test was carried out following supplementation of mice for a period of 30 days.

\section{Biochemical analysis}

Blood volumes of $1.0-2.0 \mathrm{~mL}$ were drawn from the retro-orbital plexus of eye (inner orbit) of mouse on the $1^{\text {st }}$ and $30^{\text {th }}$ day experimental period and measured for haemoglobin and serum total protein. Blood, collected before and after the swimming exercise was analyzed for blood glucose level, collected blood was transferred into vials containing EDTA and analyzed within 24 hours. Haemoglobin was measured as per the method described by Jain (1986). The other biochemical estimations were carried out by using Ambica Diagnostics Reagent Kits on Autoanalyzer Slim (SEAC).

\section{Statistical analysis}

Statistical analysis was performed with SPSS software (version 16, SPSS Inc., Chicago). Duncan multiple range test were used to test the differences between means $(\mathrm{P}<0.05)$.

\section{Results and Discussion}

\section{Proximate composition and mineral content of the selected plant material}

The proximate composition consisted of moisture, protein, total ash, crude fibre, carbohydrates and energy varied significantly among the selected plant extracts (Table 2). Significantly highest moisture content $\left(98.50 \mathrm{~g}_{100 \mathrm{~g}^{-1}}\right)$ was recorded in the A. vera gel followed by soybean whey $\left(94.70 \mathrm{~g} 100 \mathrm{~g}^{-1}\right)$, while highest amount of protein $(14.59 \mathrm{~g} 100 \mathrm{~g}$ $\left.{ }^{1}\right)$ and total ash $\left(14.33 \mathrm{~g} 100 \mathrm{~g}^{-1}\right)$ contents were recorded in fruits of T. terrestris. Eschun and $\mathrm{He}$ (2004) also reported 98.4 per cent water in raw pulp of $A$. vera while discussing the use of $A$. vera in connection with pharmaceutical and cosmetic industries. Although the protein 
content of the soybean whey in the present study is low (1.61\%), soya whey is considered as a good source of nutrient because of the presence of several essential amino acids which are in balanced amount resulting in high protein efficiency ratio (Kovalenko et al., 2006). The roots of $C$. borivilianum and the stem of $T$. cordifolia exhibited better values for protein (8.41 and 12.91, respectively) which are in conformity as reported by Singh et al., (2003). The presence of significantly highest amount of protein (14.59) and ash (14.33) in the fruit extract of T. terrestris in the present study is similar with the findings of Dastagir et al., (2014) who reported $14.20 \%$ and $10.90 \%$ of protein and ash in the fruit extract, respectively. The mineral content of $W$. somnifera in the present study was $8.35\left(\mathrm{~g} 100 \mathrm{~g}^{-1}\right)$ which is fairly nearer to the values given by Jabeen et al., (2010). The roots of $C$. borivilianum and $T$. cordifolia contained significantly highest

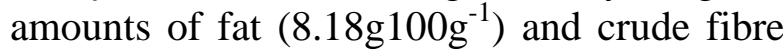

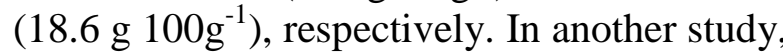
Chauhan et al., (2014) reported $1.03 \%$ and $14.83 \%$ of crude fat and fibre, respectively in the stem of $T$. cordifolia. Mahima et al., (2014), however, reported the higher amount of crude fibre $(56.42 \%)$ in stems of $T$. cordifolia. Significantly, highest carbohydrate content was recorded in the roots of $W$.

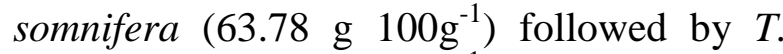
cordifolia (58.42 $\left.\mathrm{g} 100 \mathrm{~g}^{-1}\right)$. Khanna et al., (2006) similarly reported little higher content of carbohydrates $(88.7 \mathrm{mg} / 100 \mathrm{~g})$ in the roots of $W$. somnifera. The energy level in the plants extracts varied between 2.00 and $302.00 \quad$ (kcal $100 \mathrm{~g}^{-1}$ ) of which the significantly highest was recorded in the root extracts of $T$. cordifolia $\left(302.00 \mathrm{kcal} 100 \mathrm{~g}^{-1}\right)$. The mineral and trace element composition also varied significantly among the plant extracts (Table 2). Except $\mathrm{Cu}$, the estimated minerals $(\mathrm{P}, \mathrm{Ca}$ and $\mathrm{Mg}$ ) and trace elements (Fe and $\mathrm{Zn}$ ) were significantly highest in the root extracts of $T$. cordifolia. The $\mathrm{P}$ content was 7.84 times higher in the roots of $T$. cordifolia $\left(643.45 \mathrm{mg} 100 \mathrm{~g}^{-1}\right)$ compared to the fruits of $T$. terrestris $\left(82.12 \mathrm{mg} 100 \mathrm{~g}^{-1}\right)$. Calcium content of $T$. cordifoliais 48.78 times higher compared to the $C$. borivilianum in the

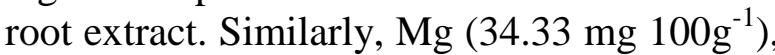
Fe (98.82mg100g $\left.\mathrm{g}^{-1}\right)$ and $\mathrm{Zn}\left(22.13 \mathrm{mg} 100 \mathrm{~g}^{-1}\right)$ contents were also significantly highest in $T$. cordifolia among all the extracts. Jabeen et al., (2010) in his study on determination of major and trace elements in ten important folk therapeutic plants from Pakistan recorded much higher values for $W$. somnifera. The variations between his values and the recorded values could be due to different soil conditions in parts of Indian and Pakistan or due to analytical procedures followed. Similar quantities of minerals and trace elements like $\mathrm{Ca} \quad(102.23 \mathrm{ppm}), \quad \mathrm{P} \quad(24.81 \mathrm{ppm}), \quad \mathrm{Fe}$ (26.06ppm), $\mathrm{Cu}$ (3.73ppm) and $\mathrm{Zn}(7.34 \mathrm{ppm})$ were also reported by Mahima et al., (2014), in the stem of $T$. cordifolia. The $\mathrm{Cu}$ content was however found significantly highest in the root extract of $W$. somnifera $(1.81 \mathrm{mg}$ $\left.100 \mathrm{~g}^{-1}\right)$. Gupta (2013), elucidated the presence of $\mathrm{Cu}$ in the stem of $W$. somnifera to the tune of $0.58 \mathrm{ppm}$.

\section{Organoleptic evaluation}

The results of organoleptic evaluation of the six PHG based on $A$. veragel and soya bean whey as base materials exhibited significant variation in colour, flavor, taste and overall acceptability (Table 3 ). In A. vera based PHG the formulation AVII scored highest in colour (4.6), flavor (4.6), taste (4.5) and overall acceptability (4.6) at the end of 270 days. The second formulation based on soyabean whey similarly, showed significant variations and the formulation SBWII recorded highest scores in colour (4.5), flavor (4.5), taste (4.5) and overall acceptability (4.5). Sahu et al., (2005) assessed the acceptability of beverages prepared from whey and mango and reported better acceptability up to 60 days. However, 
in the present study the PHG based on A. vera gel and soybean whey exhibited better acceptability up to a period of 270 days without significant variations in colour, flavor, taste and overall acceptability. This could be due to the lower moisture content of the dry granules and use of sugar syrup in the formulations. It is convincingly established that higher moisture content in food product plays a vital role in food spoilage (Ananthanarayana and Panikar, 2005). Use of sugar syrup in the present study acts as a preservative by binding moisture and thus positively influenced the acceptability for a longer period (Srilakshmi, 2004). Based on the organoleptic evaluation, two variants viz., AVII and SBWII were finally selected for further analysis.

Proximate composition, mineral and trace elements in the selected polyherbal granules

Carbohydrates were the major constituents in both AVII and SBWII, followed by protein and total ash (Table 4). Fat contents were low,

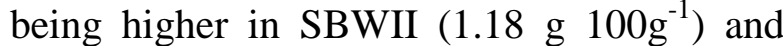

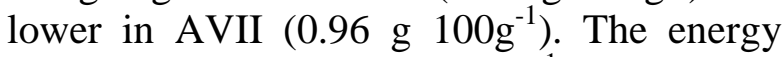
levels of AVII (378 kcal $100 \mathrm{~g}^{-1}$ ) and SBWII
(377 kcal $100 \mathrm{~g}^{-1}$ ) were higher and similar, due to their higher contribution of carbohydrates and fats, respectively. Poly herbal formulations like Garlicare tablet, ginger capsule consisting the extracts of Hypericum perforatum, Allium sativum, Zingiber officinalis and Valeriana officinalis has been shown to contain the energy levels of 330.10 kcal $100 \mathrm{~g}^{-1}$ and 372.40 kcal $100 \mathrm{~g}^{-1}$ respectively, (Hussain et al., 2009). Gupta et al., (2012) similarly exhibited that the rice flakes mix developed with incorporation of polyherbal (Mentha asiatica, Ocimum basilicum, Moringa oligfera, Zingiber officinale, Allium longicuspis and Nelum bonucifera) extract at $16 \%$ yielded the energy

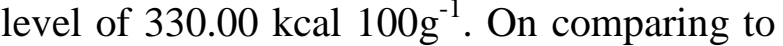
the energy level (390 kcal $100 \mathrm{~g}^{-1}$ ) of Boletus edulis Bull., one of the tastiest and most cultivated mushrooms worldwide (Jaworska and Bernas, 2009; Helenoa et al., 2015), the energy levels of PHG in the present study are close to Boletus edulis. It was also observed that the drink prepared by addition of $7.10 \%$ of the formulated granules yielded approximately $54 \mathrm{Kcal}$ of energy which is higher than the values reported by other sports drinks that are developed in India (Sahu et al., 2005).

Table.1 Formulation of poly herbal granules

\begin{tabular}{|c|c|c|c|c|c|}
\hline \multirow[t]{3}{*}{ Variants } & \multicolumn{2}{|l|}{ Base materials } & \multicolumn{3}{|c|}{ Basic components } \\
\hline & Aloe vera gel & Soybean whey & $\begin{array}{l}\text { Poly herbal } \\
\text { mixture }\end{array}$ & Sugar & $\begin{array}{l}\text { Citric } \\
\text { acid }\end{array}$ \\
\hline & $\mathbf{m L}$ & & $(\%, w / w)$ & & \\
\hline AVI & 20 & -- & 35 & 62 & 3 \\
\hline AVII & 20 & -- & 37 & 60 & 3 \\
\hline AVIII & 20 & -- & 39 & 58 & 3 \\
\hline SBWI & -- & 20 & 35 & 62 & 3 \\
\hline SBWII & -- & 20 & 37 & 60 & 3 \\
\hline SBWIII & -- & 20 & 39 & 58 & 3 \\
\hline
\end{tabular}


Table.2 Proximate composition and minerals and trace elements of the selected plant materials for poly herbal formulations

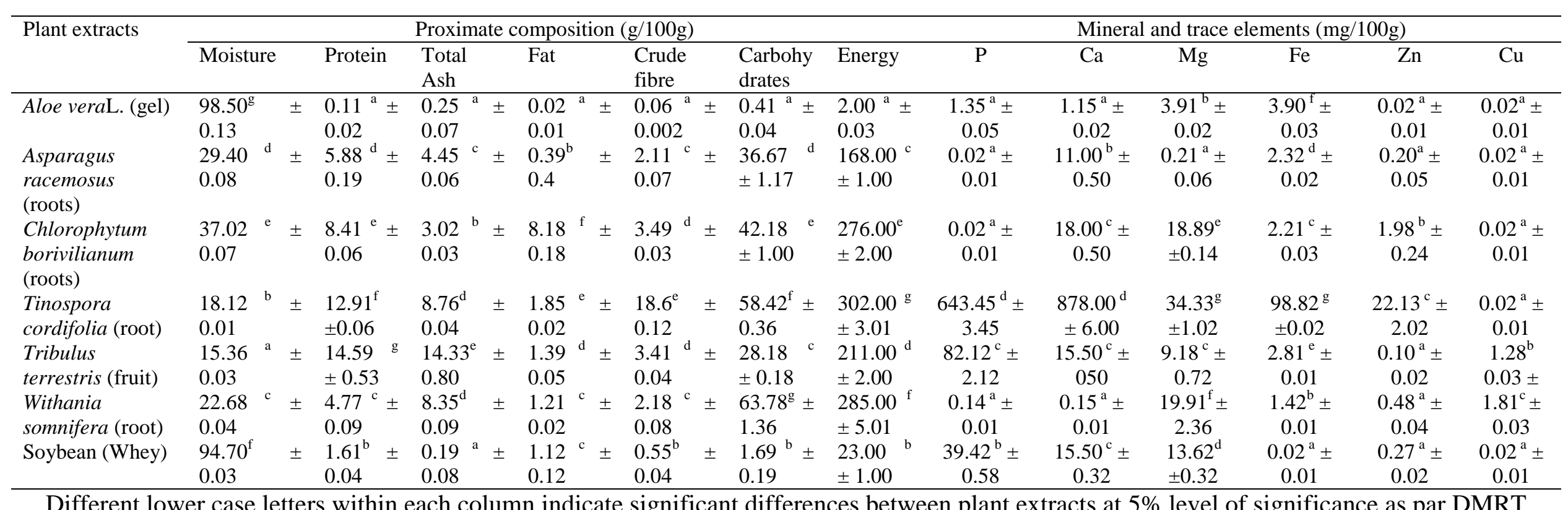


Table.3 Organoleptic scores of poly herbal granules with Aloe vera gel and Soyabean whey as base material

\begin{tabular}{|c|c|c|c|c|c|c|c|}
\hline \multirow[t]{2}{*}{$\begin{array}{l}\text { Organoleptic } \\
\text { traits }\end{array}$} & \multirow[t]{2}{*}{$\begin{array}{c}\text { Day of } \\
\text { evaluation }\end{array}$} & \multicolumn{3}{|c|}{$\begin{array}{c}\text { Poly herbal granules with Aloe } \\
\text { vera gel }\end{array}$} & \multicolumn{3}{|c|}{ Poly herbal granules withSoyabean whey } \\
\hline & & AVI & AVII & AVIII & SBWI & SBWII & SBWIII \\
\hline \multirow{6}{*}{ Colour } & 0 & $4.3^{\mathrm{a}}$ & $4.7^{\mathrm{a}}$ & $4.4^{\mathrm{a}}$ & $3.8^{\mathrm{a}}$ & $4.7^{b}$ & $3.8^{\mathrm{a}}$ \\
\hline & 30 & $4.0^{\mathrm{a}}$ & $4.6^{\mathrm{a}}$ & $4.3^{\mathrm{a}}$ & $3.8^{\mathrm{a}}$ & $4.6^{\mathrm{b}}$ & $3.9^{\mathrm{a}}$ \\
\hline & 60 & $4.2^{\mathrm{a}}$ & $4.6^{\mathrm{b}}$ & $3.8^{\mathrm{a}}$ & $3.7^{\mathrm{a}}$ & $4.6^{\mathrm{b}}$ & $3.6^{\mathrm{a}}$ \\
\hline & 90 & $4.3^{\mathrm{a}}$ & $4.6^{\mathrm{b}}$ & $3.8^{\mathrm{a}}$ & $3.9^{\mathrm{a}}$ & $4.6^{\mathrm{b}}$ & $3.8^{\mathrm{a}}$ \\
\hline & 180 & $4.1^{\mathrm{a}}$ & $4.6^{\mathrm{a}}$ & $4.1^{\mathrm{a}}$ & $3.7^{\mathrm{a}}$ & $4.6^{\mathrm{b}}$ & $3.8^{\mathrm{a}}$ \\
\hline & 270 & $3.7^{\mathrm{a}}$ & $4.6^{\mathrm{b}}$ & $3.9^{\mathrm{a}}$ & $3.6^{\mathrm{a}}$ & $4.5^{b}$ & $3.9^{\mathrm{a}}$ \\
\hline \multirow{6}{*}{ Flavor } & 0 & $4.3^{\mathrm{a}}$ & $4.7^{\mathrm{a}}$ & $4.2^{\mathrm{a}}$ & $4.3^{\mathrm{a}}$ & $4.6^{\mathrm{a}}$ & $4.2^{\mathrm{a}}$ \\
\hline & 30 & $4.2^{\mathrm{a}}$ & $4.6^{\mathrm{a}}$ & $4.0^{\mathrm{a}}$ & $4.2^{\mathrm{a}}$ & $4.6^{\mathrm{a}}$ & $4.0^{\mathrm{a}}$ \\
\hline & 60 & $4.3^{\mathrm{a}}$ & $4.6^{\mathrm{a}}$ & $4.2^{\mathrm{a}}$ & $4.3^{\mathrm{a}}$ & $4.6^{\mathrm{a}}$ & $4.1^{\mathrm{a}}$ \\
\hline & 90 & $4.3^{\mathrm{a}}$ & $4.6^{\mathrm{a}}$ & $4.3^{\mathrm{a}}$ & $4.3^{\mathrm{a}}$ & $4.5^{\mathrm{a}}$ & $4.3^{\mathrm{a}}$ \\
\hline & 180 & $4.0^{\mathrm{a}}$ & $4.6^{\mathrm{a}}$ & $4.1^{\mathrm{a}}$ & $4.1^{\mathrm{a}}$ & $4.6^{\mathrm{a}}$ & $4.1^{\mathrm{a}}$ \\
\hline & 270 & $4.0^{\mathrm{a}}$ & $4.6^{b}$ & $3.9^{\mathrm{a}}$ & $4.1^{\mathrm{a}}$ & $4.5^{\mathrm{b}}$ & $3.7^{\mathrm{a}}$ \\
\hline \multirow{6}{*}{ Taste } & 0 & $4.4^{\mathrm{a}}$ & $4.8^{\mathrm{a}}$ & $4.3^{\mathrm{a}}$ & $4.4^{\mathrm{a}}$ & $4.8^{\mathrm{a}}$ & $4.3^{\mathrm{a}}$ \\
\hline & 30 & $4.3^{\mathrm{a}}$ & $4.7^{\mathrm{a}}$ & $4.2^{\mathrm{a}}$ & $4.3^{\mathrm{a}}$ & $4.7^{\mathrm{a}}$ & $4.2^{\mathrm{a}}$ \\
\hline & 60 & $4.3^{\mathrm{a}}$ & $4.6^{\mathrm{a}}$ & $4.2^{\mathrm{a}}$ & $4.3^{\mathrm{a}}$ & $4.7^{\mathrm{a}}$ & $4.3^{\mathrm{a}}$ \\
\hline & 90 & $4.1^{\mathrm{a}}$ & $4.6^{b}$ & $3.9^{\mathrm{a}}$ & $4.3^{\mathrm{a}}$ & $4.6^{\mathrm{a}}$ & $4.3^{\mathrm{a}}$ \\
\hline & 180 & $4.1^{\mathrm{a}}$ & $4.6^{\mathrm{b}}$ & $3.9^{\mathrm{a}}$ & $4.2^{\mathrm{a}}$ & $4.6^{\mathrm{a}}$ & $3.9^{\mathrm{a}}$ \\
\hline & 270 & $3.9^{\mathrm{a}}$ & $4.5^{b}$ & $4.0^{\mathrm{a}}$ & $3.8^{\mathrm{a}}$ & $4.5^{b}$ & $3.9^{\mathrm{a}}$ \\
\hline \multirow{6}{*}{$\begin{array}{l}\text { Overall } \\
\text { Acceptability }\end{array}$} & 0 & $4.3^{\mathrm{a}}$ & $4.8^{\mathrm{a}}$ & $4.4^{\mathrm{a}}$ & $4.3^{\mathrm{a}}$ & $4.7^{\mathrm{a}}$ & $4.4^{\mathrm{a}}$ \\
\hline & 30 & $4.3^{\mathrm{a}}$ & $4.7^{\mathrm{b}}$ & $4.1^{\mathrm{a}}$ & $4.3^{\mathrm{a}}$ & 4.6 & $4.3^{\mathrm{a}}$ \\
\hline & 60 & $4.0^{\mathrm{a}}$ & $4.6^{\mathrm{b}}$ & $4.0^{\mathrm{a}}$ & $4.0^{\mathrm{a}}$ & $4.6^{\mathrm{b}}$ & $4.0^{\mathrm{a}}$ \\
\hline & 90 & $4.0^{\mathrm{a}}$ & $4.6^{\mathrm{a}}$ & $4.1^{\mathrm{a}}$ & $4.0^{\mathrm{a}}$ & $4.6^{\mathrm{a}}$ & $4.1^{\mathrm{a}}$ \\
\hline & 180 & $3.9^{\mathrm{a}}$ & $4.6^{\mathrm{a}}$ & $4.0^{\mathrm{a}}$ & $4.1^{\mathrm{a}}$ & $4.5^{\mathrm{a}}$ & $4.0^{\mathrm{a}}$ \\
\hline & 270 & $4.0^{\mathrm{a}}$ & $4.6^{\mathrm{b}}$ & $3.9^{\mathrm{a}}$ & $4.0^{\mathrm{a}}$ & $4.5^{b}$ & $3.8^{\mathrm{a}}$ \\
\hline
\end{tabular}


Table.4 Proximate composition and mineral and trace elements of the selected poly herbal granules

\begin{tabular}{lcc}
\hline Proximate composition & Formulation AVII & Formulation SBWII \\
\hline Moisture $(\mathrm{g} / 100 \mathrm{~g})$ & $2.37 \pm 0.13$ & $2.80 \pm 0.08$ \\
Protein $(\mathrm{g} / 100 \mathrm{~g})$ & $4.39 \pm 0.02$ & $4.69 \pm 0.19$ \\
Fat $(\mathrm{g} / 100 \mathrm{~g})$ & $0.96 \pm 0.01$ & $1.18 \pm 0.18$ \\
Total ash $(\mathrm{g} / 100 \mathrm{~g})$ & $3.65 \pm 0.02$ & $3.65 \pm 0.06$ \\
Crude fibre $(\mathrm{g} / 100 \mathrm{~g})$ & $0.76 \pm 0.01$ & $0.76 \pm 0.07$ \\
Carbohydrate $(\mathrm{g} / 100 \mathrm{~g})$ & $87.87 \pm 0.04$ & $86.92 \pm 0.16$ \\
Energy $(\mathrm{Kcal} / 100 \mathrm{~g})$ & $378 \pm 0.03$ & $377 \pm 0.18$ \\
\hline Mineral and trace elements (mg/100 g) & $70.20 \pm 0.02$ \\
\hline Calcium & $68.13 \pm 0.01$ & $61.55 \pm 0.02$ \\
Phosphorus & $53.67 \pm 0.02$ & $7.85 \pm 0.02$ \\
Iron & $8.63 \pm 0.03$ & $85.27 \pm 0.06$ \\
Magnesium & $83.33 \pm 0.02$ & $0.19 \pm 0.00$ \\
Copper & $0.23 \pm 0.01$ & $1.85 \pm 0.02$ \\
Zinc & $1.84 \pm 0.01$ & \\
\hline
\end{tabular}

Table.5 Storage study of the developed polyherbal granules with Aloe vera gel and Soyabean whey as base material

\begin{tabular}{lcccccccc}
\hline & \multicolumn{3}{c}{ Formulation AVII } & \multicolumn{3}{c}{ Formulation SBWII } \\
\cline { 2 - 8 } $\begin{array}{c}\text { Day of } \\
\text { storage }\end{array}$ & $\begin{array}{l}\text { Vitamin C } \\
(\mathrm{mg} / 100 \mathrm{~g})\end{array}$ & $\begin{array}{c}\text { Total } \\
\text { sugar } \\
(\mathrm{gm} / 100 \mathrm{~g})\end{array}$ & $\begin{array}{c}\text { Non- } \\
\text { reducing } \\
\text { sugar } \\
(\mathrm{gm} / 100 \mathrm{~g})\end{array}$ & $\begin{array}{c}\text { Reducing } \\
\text { sugar } \\
(\mathrm{gm} / 100 \mathrm{~g})\end{array}$ & $\begin{array}{c}\text { Vitamin C } \\
(\mathrm{gm} / 100 \mathrm{~g})\end{array}$ & $\begin{array}{c}\text { Total } \\
\text { sugar } \\
(\mathrm{gm} / 100 \mathrm{~g})\end{array}$ & $\begin{array}{c}\text { Non- } \\
\text { reducing } \\
\text { sugar } \\
(\mathrm{gm} / 100 \mathrm{~g})\end{array}$ & $\begin{array}{c}\text { Reducing } \\
\text { sugar } \\
(\mathrm{gm} / 100 \mathrm{~g})\end{array}$ \\
\hline 0 & $6.65^{\mathrm{a}}$ & $27.57^{\mathrm{a}}$ & $20.90^{\mathrm{a}}$ & $6.62^{\mathrm{a}}$ & $4.44^{\mathrm{a}}$ & $24.83^{\mathrm{a}}$ & $18.47^{\mathrm{a}}$ & $6.29^{\mathrm{a}}$ \\
30 & $6.66^{\mathrm{a}}$ & $27.52^{\mathrm{a}}$ & $20.90^{\mathrm{a}}$ & $6.62^{\mathrm{a}}$ & $4.41^{\mathrm{a}}$ & $24.83^{\mathrm{a}}$ & $18.47^{\mathrm{a}}$ & $6.29^{\mathrm{a}}$ \\
60 & $6.62^{\mathrm{a}}$ & $27.57^{\mathrm{a}}$ & $20.90^{\mathrm{a}}$ & $6.62^{\mathrm{a}}$ & $4.39^{\mathrm{a}}$ & $24.85^{\mathrm{a}}$ & $18.45^{\mathrm{a}}$ & $6.31^{\mathrm{a}}$ \\
90 & $6.60^{\mathrm{a}}$ & $27.58^{\mathrm{a}}$ & $20.89^{\mathrm{a}}$ & $6.65^{\mathrm{a}}$ & $4.38^{\mathrm{a}}$ & $24.86^{\mathrm{a}}$ & $18.44^{\mathrm{a}}$ & $6.32^{\mathrm{a}}$ \\
180 & $6.59^{\mathrm{a}}$ & $27.60^{\mathrm{a}}$ & $20.88^{\mathrm{a}}$ & $6.65^{\mathrm{a}}$ & $4.37^{\mathrm{a}}$ & $24.88^{\mathrm{a}}$ & $18.42^{\mathrm{a}}$ & $6.34^{\mathrm{a}}$ \\
270 & $6.57^{\mathrm{a}}$ & $27.60^{\mathrm{a}}$ & $20.84^{\mathrm{a}}$ & $6.68^{\mathrm{a}}$ & $4.35^{\mathrm{a}}$ & $24.88^{\mathrm{a}}$ & $18.37^{\mathrm{a}}$ & $6.35^{\mathrm{a}}$ \\
\hline
\end{tabular}

Different lower case letters within each column indicate significant differences between plant extracts at $5 \%$ level of significance as per DMRT

Table.6 Effect of poly herbal granules on the body weight of Swiss mice

\begin{tabular}{lcccc}
\hline \multirow{1}{*}{ Treatment } & \multicolumn{3}{c}{ Body weight $(\mathbf{g})$} & \multirow{2}{*}{ Per cent increase } \\
\cline { 2 - 4 } & Initial & Final & Weight gain & \\
\hline Control & $28.40^{\mathrm{a}}{ }^{ \pm} 2.05$ & $30.20^{\mathrm{a}} \pm 2.03$ & $1.27^{\mathrm{a}} \pm 0.59$ & 4.23 \\
AVII & $29.80^{\mathrm{a}} \pm 2.51$ & $33.60^{\mathrm{b}} \pm 2.13$ & $3.80^{\mathrm{b}} \pm 0.77$ & 11.40 \\
SWBII & $29.20^{\mathrm{a}} \pm 1.92$ & $33.10^{\mathrm{b}} \pm 1.78$ & $3.90^{\mathrm{b}} \pm 0.30$ & 11.80 \\
\hline \multicolumn{2}{l}{ Different lower case letters within each column indicate significant differences between treatments at } \\
5\% level of significance as per DMRT(control, $\mathrm{n}=6$; AVII and SWBII, $\mathrm{n}=10$ ) \\
\hline
\end{tabular}


Table.7 Effect of poly herbal granules on haemoglobin and serum protein level of Swiss mice

\begin{tabular}{|c|c|c|c|c|c|c|}
\hline \multirow[t]{2}{*}{ Treatment } & \multicolumn{2}{|c|}{ Haemoglobin (gm/dl) } & \multirow{2}{*}{$\begin{array}{l}\text { Per cent } \\
\text { increases in } \\
\text { hemoglobin }\end{array}$} & \multicolumn{2}{|c|}{ Serum protein (gm/dl) } & \multirow{2}{*}{$\begin{array}{c}\text { Per cent } \\
\text { increases in } \\
\text { serum protein }\end{array}$} \\
\hline & Before & After & & Before & After & \\
\hline Control & $11.84^{\mathrm{a}} \pm 0.29$ & $11.78^{\mathrm{a}} \pm 0.18$ & $-0.50^{\mathrm{a}}$ & $6.09^{a} \pm 0.27$ & $6.12^{a} \pm 0.27$ & $0.45^{\mathrm{a}}$ \\
\hline AVII & $11.56^{\mathrm{a}} \pm 0.66$ & $13.11^{\mathrm{b}} \pm 0.71$ & $11.82^{b}$ & $5.83^{\mathrm{b}} \pm 0.33$ & $6.06^{\mathrm{a}} \pm 0.24$ & $3.77^{b}$ \\
\hline SWBII & $11.39^{\mathrm{a}} \pm 0.70$ & $13.02^{\mathrm{b}} \pm 0.83$ & $12.46^{\mathrm{b}}$ & $5.64^{\mathrm{b}} \pm 0.29$ & $6.00^{\mathrm{a}} \pm 0.24$ & $6.02^{c}$ \\
\hline
\end{tabular}

Different lower case letters within each column indicate significant differences between treatments at $5 \%$ level of significance as per DMRT(control, $n=6$; AVII and SWBII, $\mathrm{n}=10$ )

Table.8 Effect of poly herbal granules on swimming performance and blood glucose level of Swiss mice

\begin{tabular}{cccccc}
\hline Treatment & $\begin{array}{c}\text { Swimming } \\
\text { time (minutes) }\end{array}$ & $\begin{array}{c}\text { Average Per } \\
\text { cent increase } \\
\text { in swimming } \\
\text { time }\end{array}$ & $\begin{array}{c}\text { Blood glucose (mg/dl) } \\
\text { Before } \\
\text { swimming }\end{array}$ & $\begin{array}{c}\text { After } \\
\text { swimming }\end{array}$ & $\begin{array}{c}\text { Percent Increase of } \\
\text { blood glucose }\end{array}$ \\
\hline Control & $147.32^{\mathrm{a}} \pm 1.48$ & - & $82.74^{\mathrm{a}} \pm 1.92$ & $138.26^{\mathrm{b}} \pm 6.04$ & 40.07 \\
AVII & $231.01^{\mathrm{b}} \pm 2.33$ & 36.23 & $83.18^{\mathrm{a}} \pm 1.58$ & $87.11^{\mathrm{a}} \pm 1.73$ & 4.51 \\
SWBII & $237.50^{\mathrm{c}} \pm 2.14$ & 37.97 & $82.98^{\mathrm{a}} \pm 2.02$ & $86.78 \mathrm{a} \pm 2.14$ & 4.37 \\
\hline
\end{tabular}

Different lower case letters within each column indicate significant differences between treatments at $5 \%$ level of significance as per DMRT(control, $n=6$; AVII and SWBII, $n=10$ )

The results pertaining to the minerals of the PHG illustrated that comparatively higher contents of $\mathrm{Ca}\left(70.20 \mathrm{mg} 100 \mathrm{~g}^{-1}\right), \mathrm{Mg}(85.27$ $\left.\mathrm{mg} 100 \mathrm{~g}^{-1}\right)$ and $\mathrm{P}\left(61.55 \mathrm{mg} 100 \mathrm{~g}^{-1}\right)$ were observed in SBWII than the AVII. In AVII the $\mathrm{Ca}, \mathrm{Mg}$ and $\mathrm{P}$ contents were 68.13, 83.33 and $53.67 \mathrm{mg} 100 \mathrm{~g}^{-1}$, respectively (Table 4). The level of Calaid down by WHO is $450-1200 \mathrm{mg}$ per day, which is in agreement to the one found in the present PHG. The analysis of trace elements reveals that, $\mathrm{Zn}$ and $\mathrm{Fe}$ content were

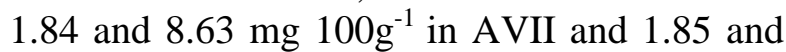

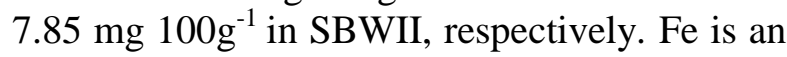
element essential for healthy immune system and energy production (Ullah et al., 2012), while $\mathrm{Zn}$ containing metalloenzymes participates in the metabolism, growth and repair of the tissue and cell membrane stabilization and improves the immune response, especially $\mathrm{T}$-cell mediated response (Bhowmik et al.,2010).

The retention of appreciable amount of $\mathrm{Zn}$ and Fe in both the PHG viz., AVII and SBWII have the potential in complementing the widespread deficiency of $\mathrm{Zn}$ and $\mathrm{Fe}$ in humans (Bailey et al., 2015). 


\section{Shelf life of the selected poly-herbal granules}

Stability of the primary phytoconstituents of PHG has recently been recognized as essential for quality control to support their shelf life. The most important aspect in the evaluation of the stability study of a product is its storage condition. In the present study four parameters viz., vitamin $\mathrm{C}$, total sugar, non- reducing sugar and reducing sugar of the PHF (AVII and SBWII) were determined during the storage which resulted in no significant losses of the phytoconstituents (Table 5). It has been well documented that ascorbic acid is an unstable compound and on long storage it causes degradation (Ancuceanu et al., 2015). However, no significant degradation of vitamin $\mathrm{C}$ has been observed for 270 days of storage in the study. Though non-significant, the reducing sugar slightly increased in AVII with progress of storage period, which might be attributed to the hydrolysis of non-reducing sugar. The retention of the determined phytoconstituents in the present study for longer periods (270days) might be due to the antimicrobial and antioxidative activity of $A$. racemosus (Alok et al., 2013) and W. somnifera (Chatterjee et al., 2010). Moisture levels in a food material greatly affect its physical, chemical and microbial stability and have a critical effect on product's shelf-life (Gulati et al., 2015). The extension of shelf life of the formulated PHG might be due to the reduced moisture to the tune of 2.37 and $2.80 \%$, respectively in AVII and SBWII, coupled with antimicrobial and antioxidant activity of the extracts. Sahu et al., (2005) however reported that due to high moisture content the storage life of whey based mangoherbal (lemongrass) beverage was comparatively low.

\section{In vivo evaluation in Swiss mice}

The anti-fatigue activity of the PHG, viz., AVII and SBWII was evaluated by FST in Swiss mice. The FST model in mice was a reliable measure of anti-fatigue treatment as established in both laboratory animals and humans (Jung et al., 2007; Jia and $\mathrm{Wu}, 2008)$. Changes in the body weight of mice, swimming time and corresponding biochemical parameters including haemoglobin, serum protein and blood glucose level were observed.

The body weights of mice increased during the experimental period which showed significantly higher body weights and weight gain in both the PHG supplemented mice compared to the control at the final stage (Table 6). Compared to the control, AVII and SWBII might have resulted in the increase in body weight of mice by 11.40 and 11.80 percent, respectively. However, no significant differences were observed between AVII and SWBII with respect to body weight and weight gain of mice. Similar result of increased body weight in mice was also observed due to feeding of watersoluble polysaccharides from Morinda officinalis (Zhang et al., 2009).

Oral administration of PHG in mice for 30 days caused a significant increase in haemoglobin levels compared to control, which resulted in 11.82 and 12.46 percent increase in haemoglobin due to AVII and SWBII, respectively (Table 7). Enhanced haemoglobin and haematological profile in animals has been reported on consumption of root extracts from A. racemosus (Rakhate et al., 2010) and $C$. borivilianum (Kenjale et al., 2007). The increased haemoglobin levels in mice might be due to the presence of $A$. racemosus and $C$. borivilianum extracts in both the PHG (AVII and SWBII). However, no significant difference of serum protein level was observed among the treatments in Swiss mice. In comparison to control $(0.45 \%)$, the serum protein levels increased by 3.77 and 6.02 percent during the test period due to the oral administration of AVII and SWBII, respectively (Table 7).

\section{Anti-fatigue activity}

The anti-fatigue activity of the Swiss mice carried out by inducing FST exhibited significant variations among the treatments (Table 8). The mean swimming time to exhaustion in the supplemented group and the 
control were 231.02 (AVII), 237.50 (SBWII) and 147.32 minutes, respectively. The results also revealed that the swimming times to exhaustion of the supplemented groups were 36.23 (AVII) and 37.97 (SBWII) per cent longer than that of the control group. Reduction in the physiological fatigue and increase in the physical performance due to supplementation of Curcumin for enhanced muscular glycogen content on Swiss mice was also reported (Huang et al., 2015). In the present study the increase in swimming time with concomitant reduction in fatigue might be due to the presence of health promoting bio constituents present in PHG containing various herbs (Jung et al., 2004).

With reference to the blood glucose there was slight increase in the PHG supplemented (AVII and SBWII) groups after swimming. However, the increase in control group was tremendous (40.07\%) compared to AVII (4.51\%) and SBWII (4.37\%), respectively. It was estimated that higher blood glucose level of the control group was due to shorter swimming time than that of the PHG supplemented group. This extreme variation in blood glucose between control and supplemented groups indicated positive and beneficial effects of developed supplement in reducing the fatigue. The blood glucose levels increased during stress (Dominiczak, 1999) is an indication of adaptogenic activity (Sen et al., 1992) due to stress induced hyperglycemia and release of cortisol (Sadock and Sadock, 2003). Increased plasma cortisol influences the mobilization of stored fat and carbohydrate reserves (Tache and Salye, 1976) that influences the increase in blood glucose level which is reversed by antistress agents (Sen et al., 1992). The present experiment exhibited the anti-fatigue and adaptogenic activity of PHG which might have induced minute increase of blood glucose levels as compared to tremendous increase in blood glucose level in the control group. Several other scientists also reported similar findings while working on different herbs (Dhuley, 2000 and Kenjale et al., 2007).
In conclusion the PHG (AVII and SBWII) developed from extracts of Asparagus racemosus, Chlorophytum borivilianum, Tinospora cordifolia, Tribulus terrestris and Withania somnifera using Aloe vera gel and soyabean whey as basic components exhibited adequate amount of carbohydrates, proteins, fats, crude fibre, total ash, minerals and trace elements. The oral administration of PHG displayed increase in body weight, haemoglobin and serum protein level in mice. The prolonged exhaustive exercise time and minute increase in blood glucose level following FST in Swiss mice for PHG supplemented groups compared to the control illustrated the anti-fatigue activity of the developed PHG.

\section{Acknowledgement}

The authors acknowledge with thanks to Dr. V. Vadlamudi, Retd. Head of Dept. of Pharmacology, College of Animal and Veterinary Sciences, MAFSU, Parbhani, Maharashtra, India.

\section{References}

Afolabi, S.O., Akindele, A.J., Awodele, O., Anunobi, C.C. andAdeyemi, O.O. 2012. A 90 day chronic toxicity study of Nigerian herbal preparation DAS-77 in rats. BMC Complementary and Alternative Med., 12: 79.

Alok, S., Jain, S.K., Verma, A., Kumar, M., Mahor, A. and Sabharwal, M. 2013. Plant profile, Phytochemistry and Pharmacology of Asparagus racemosus (Shatavari): a review. Asian Pacific .J. Trop. Dis., 3: 242-251.

Ament, W. and Verkerke, G.J. 2009. Exercise and fatigue. Sports Med., 39: 389-422.

Amerine, M.A., Pangborn, R.M. and Roessler. E.B. 1965. Principles of sensory evaluation of food. In: Food Science and Technology Monographs. Academic Press, New York, 338-339.

Ananthanarayan, R. and Panikar, C.K.J. 2005. Textbook of Microbiology. $7^{\text {th }}$ edition, published by Orient Longman Pvt. Ltd. 
Chennai, India.

Ancuceanu, R., Arama, C., Neagu, A.F., Dinu, M., Hovanet, M.V., Olaru, O.T., Popescu, C., and Anghel, A.I. 2015. Ascorbic acid is virtually degraded in dried herbal products-An assessment of six plant species. Farmacia, 63(5): 745-750.

AOAC. 1996. Official Methods of Analysis of AOAC International. Association of Official Analytical Chemists, Washington, DC., USA.

Bae, J.W., Kim, D.H., Lee, W.W., Kim, H.Y. and Son, C.G. 2015. Characterizing the human equivalent dose of herbal medicines in animal toxicity studies. $J$. Ethnopharmacol., 162: 1-6.

Bailey, R.L., West Jr, K.P. and Black, R.E. 2015. The Epidemiology of Global Micronutrient Deficiencies. Annals Nutri. Metabolism, 66: 22-33.

Bhowmik, D., Chiranjib, K.P. and Kumar, S. 2010. A potential medicinal importance of zinc in human health and chronic disease. Int. J. Pharma. Biomed. Sci., 1: 5-11.

Bopana, N. and Saxena, S. 2007. Asparagus racemosus Ethropharmacological evaluation and conservation needs. $J$. Ethropharmacol., 110: 1-15.

Borsini, F. and Meli, A. 1988. Is the forced swimming test a suitable model for revealing antidepressant activity? Psychopharmacol., 94: 147-160.

Chatterjee, S., Srivastava, S., Khalid, A., Singh, N., Sangwan, R.S., Sidhu, O.P., Roy, R., Khetrapal, C.L. and Tuli, R. 2010).Comprehensive metabolic fingerprinting of Withaniasomnifera leaf and root extracts. Phytochem., 71: 10851094.

Chauhan, D.K., Puranik, V. and Mishra, V. 2014. Analysis of stem of Tinosporacordifolia, leaves of Andrographispaniculata and root and leaves of Boerhaaviadiffusa for nutritional and phytochemical composition. Int. J. Food and Nutri. Sci., 3(4): 104-111.

Coombes, J.S., Rowell, B., Dodd, S.L.,
Demirel, H.A., Naito, H., Shanely, R.A. and Powers, S.K. 2002. Effects of vitamin E deficiency onfatigue and muscle contractile properties. European $J$. Applied Physiol., 87: 272-7.

Dastagir, G., Hussain, F. and Khattak, K.F. 2014. Nutritional evaluation of plants of family Zygophyllaxeae and Euphorbiaceae. Pak. J. Bot., 46(5): 17031707.

Dhuley, J.N. 1997. Effect of some Indian herbs on macrophage functions in ochratoxin a treated mice. J. Ethnopharmacol., 58: 1520.

Dominiczak, B. 1999. Chapter Ro, Glucose Homestasis and Fuel Metabolism in Medical Biochemistry. Mosby. London: 257-258.

DuBois, M., Gilles, K.A., Hamilton, J.K., Rebers, P.A. and Smith, F. 1956. Colorimetric Method for Determination of Sugars and Related Substances. Anal. Chem., 28(3): 350-356.

Eschun, K. and He, Q. 2004. Aloe vera A valuable ingredient for the food, pharmaceutical and cosmetic industries A review. Erit. Rev. Food Sci. Nutr., 44: 91-96.

Gulati, T., Datta, A.K., Doona, C.J., Ruan, R.R. and Feeherry, F.E. 2015. Modeling moisture migration in a multi-domain food system: Application to storage of a sandwich system. Food Res. Int., 76: 427-438.

Gupta, E., Sinha, J.andDubey, R.P. 2012. Utilization of Dehydrated Herbs in the Formulation of Value Added Snack "Rice Flakes Mix”. J. Food Process Technol., S1-002. doi:10.4172/2157-7110.S1-002.

Gupta, J. 2013. Trace Metal Analysis in Withaniasomnifera. Oriental J. Chem., 29(3):1099-1101.

Gupta, P.K. 2000. Soil, plant, water and fertilizer analysis, Jodhpur, Agrobios (India), pp: 274-275 and 323-324.

Helenoa, S.A., Ferreirac, R.C., Antonioa, A.L., Queiroz, M.R.P., Barrosa, L. and Ferreira, I.C.F.R. 2015. Nutritional value, bioactive compounds and antioxidant properties of 
three edible mushrooms from Poland. Food Biosci., II: 48- 55.

Heng, M.Y., Tan, S.N., Yong, J. W. H. and Ong, E.S. 2013. Emerging green technologies for the chemical standardization of botanicals and herbal preparations. Trends in Anal. Chem., 50: $1-10$.

Holmes, P.V. 2003. Rodent models of depression: reexamining validity without anthropomorphic inference. Crit. Rev. Neurobiol., 15: 143-174.

Huang, W.C., Chiu, W.C., Chuang, H.L., Tang, D.W., Lee, Z.M., Wei, L., Chen, F.A. and Huang, C.C. 2015. Effect of Curcumin Supplementation on Physiological Fatigue and Physical Performance in Mice. Nutrients, 7: 905-921.

Jabeen, S., Shah, M.T., Khan, S. and Hayat, M.Q. 2010. Determination of major and trace elements in ten important folk therapeutic plants of Haripur basin. Pak. J. Med. Plants Res., 4: 559-566.

Jain, N.C. 1986. Schalm's veterinary Hematology. 4th End. Lea and Febiger, 600. Washinngton Square, Philadelphia, USA.

Jaworska, G. and Bernas, E. 2009. The effect of preliminary processing and period of storage on the quality of frozen Boletus edulis (Bull: Fr.) mushrooms. Food Chem., 113: 936-943.

Jia, J.M. and Wu, C.F. 2008. Antifatigue Activity of Tissue Culture Extracts of Saussureainvolucrata. Pharmacutical Biol., 46: 433-436.

Jung, K.A., Han, D., Kwon, E.K., Lee, C.H. and Kim, Y.E. 2007. Antifatigue effect of Rubuscoreanus Miquel extract in mice. $J$. Medicinal Food, 10: 689-693.

Jung, K., Kim, I.H. and Han, D. 2004. Effect of medicinal plant extracts on forced swimming capacity in mice. $J$. Ethnopharmacol., 93: 75-81.

Kenjale, R.D., Shah, R.K. and Sathaye, S.S. 2007. Anti-stress and anti-oxidant effects of roots of Chlorophytumborivilianum (Santapau and Fennades. Indian J. Experimental Biol., 45: 974-979.
Khanna, P.K., Kumar, A., Ahuja, A. and Kaul, M.K. 2006. Biochemical composition of roots of Withaniasomnifera (L.) Dunal., Asian J. Plant Sci., 5(6): 1061-1063.

Kovalenko, I.V., Rippke, G.R. and Hurburgh, C.R. 2006. Determination of Amino Acid Composition of Soybeans (Glycine max) by Near-Infrared Spectroscopy. J. Agri. Food Chem., 54: 3485-3491.

Lamba, H.S. Bhargava, C.S. Thakur, M. and Bhargava, S. 2011. A-glucosidase and aldosereductase inhibitory activity in vitro and anti-diabetic activity in vivo of Tribulus terrestris L. Dunal), Int. J. Pharmacy and Pharma. Sci., 3: 270-272.

Lee, B.R., Lee, J.H. andAn, H.J. 2012. Effects of Taraxacumofficinale on fatigue and immunological parameters in mice. Mol., 17: 13253-65.

Mahima, R.A., Prakash, A., Verma, A.K., Kumar, V. and Roy, D. 2014. Proximate and Elemental Analysis of Tinosporacordifolia stem. Pakistan J. Biol. Sci., 17(5): 744-747.

Mehta, R.K. and Agnew, M.J. 2012. Influence of mental workload on muscle endurance, fatigue, and recovery during intermittent static work. European J. Appl. Physiol., 112: 2891-902.

Mukhopadhyay, B., Chakraborty, A. and Ghosal, S. 2001. Immunomodulatory properties of some Indian medicinal plants. In Emerging Drugs. PID Publications by Mori, A. and Satoh, T. Eds.) Westbury, USA. 1:445-460.

NIN. 1983. Annnual of laboratory techniques. 2nd Edn. Indian Council of Medical Research, Hyderabad.

Niranjan, R.M. and Kanaki, S. 2008. Phytochemical Standardization of Herbal Drugs and Polyherbal Formulations. Bioactive Mol. Med. Plants, Pp. 349-369.

Nybo, L. 2003. CNS fatigue and prolonged exercise: Effect of glucose supplementation. Med. Sci. Sports and Exercise, 35: 589-594.

Radha, M.H., and Laxmipriya, N.P. 2015. Evaluation of biological properties and clinical effectiveness of Aloe vera: A 
systematic review. J. Traditional and Complementary Med., 5: 21-26.

Rakhate, D.H., Ukey, S., Mangle, L.N. and Deshmukh, B.S. 2010. Effect of dietary supplementation of shatavari (Asparagus racemosusWild) on haematobiochemical parameters of broilers. Vet. World, 3(6): 280-281.

Sadock, B.J. and Sadock, V.A. 2003. Major depression and bipolar disorder Kapalan and Sadock's synopsis of psychiatry, 9th Edn. Lippincott. Williams and Wilkins, Philadelphia, 534-590.

Sahu, C., Patel, S. and Choudhary, P.L. 2005. Technology for manufacture of whey based mango-herbal (lemongrass) beverage. J. Food Sci. Technol., 42(5): 421-424.

Sen, P., Maiti, P.C., Puri, S. and Ray, A. 1992. Mechanism of antistress activity of Ocimum sanctum(Linn.), eugenol and Tinospor amalabarica in experimental animals. Indian J. Experimental Biol., 30: 592-596.

Sen, S. and Chakraborty, R. 2016. Revival, modernization and integration of Indian traditional herbalmedicine in clinical practice: Importance, challenges and future. J. Traditional and Complementary Med., doi.org/10.1016/j.jtcme.2016.05.006. 111.

Singh, S.S., Pandey, S.C., Srivastava, S., Gupta, V.S., Patro, B. and Ghosh, A.C. 2003. Chemistry and medicinal properties of Tinospora cordifolia. Indian $J$. Pharmacol., 35: 83-91.

Somogyi, M. 1952. Estimation of sugars by colorimetric method. J. Biol. Chem., 200: 245.
Srilakshmi, B. 2004. Food Science, Third Edition, New Age International Publishers, pp: 294.

Tache, Y. and Selye. 1976. Shift in adenohypophyseal activity during chronic intermittent immobilization of rats. Neuroendocrinol., 22: 325-336.

Tharakan, B., Dhanasekaran, M. andManyam, B.V. 2005. Antioxidant and DNA protecting properties of anti-fatigue herb Trichopus zeylanicus. Phytother. Res., 19: 669-673.

Ullah, R., Khader, J.A., Hussain, I., AbdElsalam, N.M., Talha, M. and Khan, N. 2012. Investigation of macro and micro-nutrients in selected medicinal plants. African J. Pharmacol., 6: 18291832.

Uthayathas, S., Karuppagounder, S.S., Tamer, S.B., Parameshwaran, K., Degim, T., Suppiramaniam, V. and Dhanasekaran, M. 2007. Evaluation of neuroprotective and anti-fatigue effects of sildenafil. Life Sci., 81: 988-992.

WHO. 2013. WHO Traditional Medicine Strategy:2014-2023. World Health Organization. Geneva. ISBN 978924 1506090 (NLM classification: WB 55).

You, L.J., Zhao, M.M., Regenstein, J.M. and Ren, J.Y. 2011. In vitro antioxidant activity and in vivo anti-fatigue effect of loach (Misgurnus anguillicaudatus) peptides prepared by papain digestion. Food Chem., 124: 188-94.

Zhang, H., Li, J., Li, G., Wang, D., Long-ping Zhu, L. and Yang, D. 2009. Structural characterization and anti-fatigue activity of polysaccharides from the roots of Morinda officinalis. Int. J. Biol. Macromol., 44: 257-261.

\section{How to cite this article:}

Luna Dutta Baruah, Rohini Devi, Dhruba Jyoti Nath, Vijaya Nalwade, Asha Arya and Sudhir Rajurkar. 2017. Development of Poly Herbal Granules and Its Anti- Fatigue Efficacy in Swiss Mice. Int.J.Curr.Microbiol.App.Sci. 6(4): 2164-2178. doi: https://doi.org/10.20546/ijcmas.2017.604.254 